\title{
PENINGKATAN KEAKTIFAN DAN MOTIVASI BELAJAR BIOLOGI MELALUI DISCOVERY LEARNING PADA SISWA KELAS XI IPA ICT 2 SMA MUHAMMADIYAH 1 KARANGANYAR TAHUN PELAJARAN 2014/2015
}

\author{
IMPROVING ACTIVITY AND MOTIVATION BIOLOGY LEARNING THROUGH \\ DISCOVERY LEARNING FOR STUDENTS IN CLASS XI IPA ICT 2 \\ SMA MUHAMMADIYAH 1 KARANGANYAR \\ ACADEMIC YEAR 2014/2015
}

\author{
YULAEKA MAWAR DANI, MARIDI, BOWO SUGIHARTO \\ Program Studi Pendidikan Biologi \\ Fakultas Keguruan dan Ilmu Pendidikan \\ Universitas Sebelas Maret \\ Jl. Ir. Sutami 36 A, Surakarta, 57126, Indonesia \\ *Corresponding Author: yulaeka_md28@yahoo.com
}

Manuscript received : 11 Januari 2016 Revision accepted: 22 Maret 2016

\begin{abstract}
The objective of this research is to improve student's activity and motivation of class XI IPA ICT 2 SMA Muhammadiyah 1 Karanganyar academic year 2014/2015. The result of the observation which is student appeared unenthusiastic attitude towards learning is being implemented, so its needed a learning model which accommodate student's activity and motivation learning. One of the models that accommodate and treat student's activity and motivation learning less is discovery learning model. Kind of this research is classroom action research.The methods of data collection are through observation, questionnaire, and interviews. The data are in the form of students' activity and motivation at every phase of discovery learning models in each cycle of the action. The analysis of the quality of percentace average observation and questionnaire of student's activity and motivation learning. The results of the application of discovery learning model showed an increase of the quality of student's activity and motivation. The observation quality student's activity in the pre cycle is $38,82 \%$, the first cycle is $66,76 \%$, and the second cycle is $83,71 \%$. The questionnaire quality student's activity in the pre cycle is $51,12 \%$, the first cycle is $75,13 \%$, and the second cycle is $78,68 \%$. The observation quality student's motivation in the pre cycle is $42,86 \%$, the first cycle is $67,30 \%$, and the second cycle is $79,89 \%$. The questionnaire quality student's motivation in the pre cycle is $49,29 \%$, the first cycle is $71,86 \%$, and the second cycle is $76,55 \%$.Based on the result of the research, it can conclude that the application of discovery learning model can improve student's activity and motivation learning.
\end{abstract}

Keywords: Activity, Motivation, Discovery Learning

\section{PENDAHULUAN}

Hasil observasi proses pembelajaran di kelas XI IPA ICT 2 SMA Muhammadiyah 1 Karanganyar menunjukkan bahwa pembelajaran masih berpusat pada guru (teacher centered) sehingga siswa cenderung bersikap pasif dalam pembelajaran. Pembelajaran biologi yang tepat adalah dengan melibatkan siswa pada kegiatan yang berhubungan langsung dengan objek belajar sehingga dapat memperoleh pengalaman secara langsung dari berbagai sumber belajar (Slavin, 2006). Siswa bersikap tidak antusias terhadap pembelajaran yang sedang dilaksanakan. Siswa cenderung mengobrol dengan teman sebangku, mengerjakan tugas mata pelajaran lain saat kegiatan belajar mengajar dimulai, keributan dalam kelas saat pelajaran berlangsung, tidak bisa menjawab pertanyaan yang diberikan oleh guru, tidak mau bertanya tentang materi yang dia rasa belum menguasai, mengantuk saat mendengarkan materi pelajaran yang disampaikan guru. Masalah yang berkaitan dengan keaktifan dan motivasi belajar biologi siswa dipilih karena keaktifan dan motivasi belajar merupakan komponen penting dalam pembelajaran (Slavin, 2006).

Berdasarkan hasil observasi keaktifan dan motivasi belajar siswa sebelum tindakan selama 2 jam pelajaran diperoleh data sebagai berikut siswa yang terlibat dalam seluruh aktivitas pembelajaran sebesar $48 \%$, siswa menjawab pertanyaan dari guru sebesar $52 \%$, siswa yang berpendapat dalam pelajaran $22 \%$, 
siswa yang menanggapi pernyataan guru maupun siswa lain 33\%, siswa yang mengerjakan tugas secara kelompok $67 \%$, siswa yang tekun dan ulet dalam menghadapi tugas sebesar 33\%, siswa yang antusias dalam menjumpai permasalahan 52\%, siswa yang senang mengerjakan tugas dengan mandiri 44\%, siswa yang merasa bosan pada tugas $41 \%$, siswa yang mempertahankan pendapat saat diskusi $33 \%$.

Ada beberapa alternatif model pembelajaran yang dapat digunakan untuk meningkatkan keaktifan dan motivasi belajar, antara lain yaitu: Project Based Learning, Problem Based Learning, Inquiry, Discovery learning, Active Learning, dan sebagainya. Pada penelitian ini dipilih model pembelajaran discovery learning sebagai alternatif solusi untuk meningkatkan keaktifan dan motivasi belajar di kelas XI IPA ICT 2 SMA Muhammadiyah 1 Karanganyar. Discovery learning dipilih karena memiliki sintaks yang sederhana untuk dilakukan dengan kemampuan rata-rata siswa yang secara umum bisa melakukannya.

Discovery learning melibatkan siswa untuk menyajikan informasi yang mengharuskan mereka menemukan hubungan dalam informasi berupa pemahaman terhadap informasi (Bennett, 2003). Discovery learning melihat murid sebagai pemilik peran yang jauh lebih aktif dalam pembelajaran mereka dan pendukung pendekatan ini berpendapat bahwa peningkatan belajar peserta didik disebabkan partisipasi aktif mereka dalam proses belajar (Patrick, 2012).

Proses pembelajaran yang dilakukan siswa dalam discovery learning menurut Vermans (2003) terdapat 5 sintaks yaitu orientation, hypotesis generation, hypotesis testing, conclusion, dan regulation. Sintaks tersebut mengakomodasi keaktifan belajar siswa meliputi keaktifan lisan dan mental pada saat berdislusi, menyatakan pendapat, merumuskan masalah, dan membuat hipotesis pada tahap orientation dan hypotesis generation, keaktifan mototrik untuk melakukan kegiatan penelitian, keaktifan menulis pada pembuatan perencanaan dan laporan, keaktifan menggambar pada pembuatan bahan presentasi yang dilakukan pada tahap hypotesis testing, serta keaktifan mendengarkan, keaktifan visual, dan keaktifan emosional dalam seluruh aktivitas pembelajaran.

Discovery learning mendesak peserta didik untuk melakukan eksplorasi terhadap permasalahan yang disajikan dalam pembelajaran. Bruner (1961) sangat mengkritik terhadap sistem pembelajaran yang diprogram dalam pembelajaran karena menyebabkan peserta didik menjadi pengikut dan mencegah peserta didik menjadi kreatif. Bruner mendorong guru untuk membantu peserta didik menghadapi masalah secara individual atau dalam bentuk kelompok. Keraro, et.al. juga menjelaskan bahwa kerjasama siswa dalam pembelajaran peta konsep kooperatif, meningkatkan motivasi siswa dalam pembelajaran biologi (2007).
Siswa yang tidak aktif dalam kegiatan pembelajaran disebabkan rendahnya motivasi belajar pada diri siswa (Djaali, 2011). Motivasi tidak timbul secara tibatiba/spontan, melainkan timbul akibat dari partisipasi, pengalaman, dan kebiasaan pada waktu belajar (Sardiman, 2012). Motivasi merupakan faktor psikologis penting dalam proses pembelajaran. Motivasi dibangkitkan melalui situasi stimulus bersama ingatan untuk dapat mempengaruhi siswa sedemikian rupa sesuai hukum mekanik sehingga berfungsi dalam mengarahkan, mengaktifkan dan meningkatkan partisipasi siswa dalam proses pembelajaran (Shihusa \& Keraro, 2009; Solomon, 1986; Tasiwan, 2013).

\section{METODE PENELITIAN}

Penelitian dilaksanakan di kelas XI IPA ICT 2 SMA Muhammadiyah 1 Karanganyar tahun pelajaran 2014/2015. SMA Muhammadiyah 1 Karanganyar beralamat di Jalan Brigjen Slamet Riyadi, Tegal Gede, Karanganyar.

Prosedur penelitian mengikuti model yang dikembangkan oleh Kemmis dan Mc. Taggart (Kusumah \& Dwitagama, 2012) berupa model spiral yang terdiri dari tahap perencanaan, tindakan, observasi, dan refleksi. Tahap perencanaan pembelajaran meliputi penyusunan instrumen pembelajaran dan instrumen penelitian. Instrumen pembelajaran yang dipersiapkan dan disusun yaitu silabus RPP, LKS, lembar penilaian sikap, serta lembar penilaian keterampilan. Instrumen penelitian yang disusun dan dipersiapkan yaitu pedoman observasi, lembar observasi keaktifan, lembar observasi motivasi, lembar observasi keterlaksanaan sintaks, angket keaktifan, angket motivasi, serta peralatan dokumentasi.

Pelaksanaan tindakan berupa penerapan model pembelajaran discovery learning pada untuk meningkatkan keaktifan dan motivasi belajar biologi siswa. Observasi keaktifan dan motivasi belajar siswa dilakukan selama pelaksanaan tindakan berupa penerapan model pembelajaran discovery learning. Observasi juga dilakukan terhadap keterlaksanaan sintaks model pembelajaran discovery learning. Angket keaktifan dan motivasi belajar siswa diberikan pada akhir pelaksanaan tindakan.

Tahap refleksi merupakan analisis proses terhadap penerapan model pembelajaran discovery learning pada materi sistem pertahanan manusia (imunitas) di kelas XI IPA ICT 2 SMA Muhammadiyah 1 Karanganyar. Hasil analisis tahap refleksi dijadikan sebagai dasar perencanaan tindakan pada siklus berikutnya.

Kegiatan pengumpulan data dilakukan di 5 fase model pembelajaran discovery learning, yaitu fase rientation, hypotesis generation, hypotesis testing, conclusion, regulation (Planning, Monitoring, 
Evaluation). Metode pengambilan data berupa 3 metode berbeda, yaitu observasi, angket, dan wawancara, sehingga validitas data menggunakan teknik triangulasi metode (Moleong, 2010).

Observasi dilakukan terhadap keaktifan dan motivasi belajar siswa mengunakan lembar observasi keaktifan dan motivasi. Angket keaktifan dan motivasi belajar siswa menggunakan lembar angket keaktifan dan motivasi belajar siswa. Wawancara pertanyaan siswa menggunakan pedoman wawancara. Dokumentasi penelitian berupa foto dan rekaman video proses pembelajaran sebagai pendukung data keaktifan dan motivasi hasil observasi, angket, dan wawancara serta verifikasi keterlaksanaan kegiatan pembelajaran.

Data penelitian berupa hasil observasi dan angket keaktifan dan motivasi belajar siswa yang dianalisis berdasarkan persentase kenaikan dari rata-rata capaian tiap indikator keaktifan dan motivasi belajar siswa. Skor observasi keaktifan dan motivasi diperoleh dengan menjumlahkan total nilai tiap indikator lalu dibagi jumlah seluruh siswa dan dikalikan $100 \%$.

\section{HASIL DAN PEMBAHASAN}

Hasil tindakan penerapan model pembelajaran discovery learning berupa hasil persentase keaktifan ditunjukkan pada Gambar 1.1 dan Gambar 1.2.

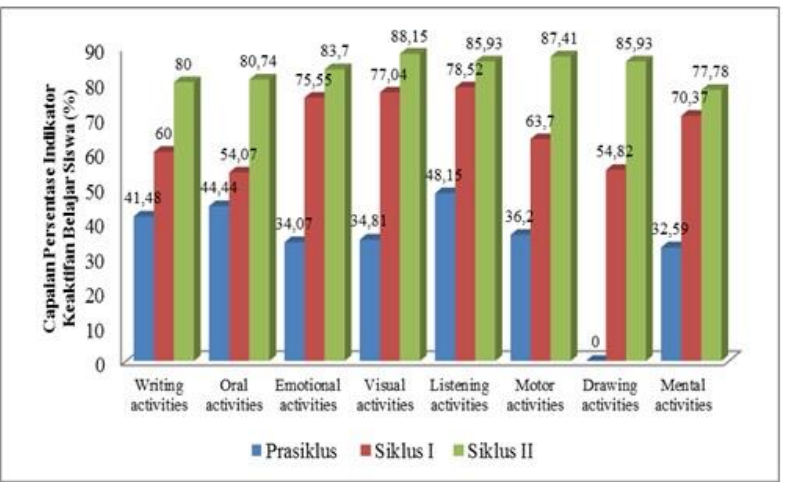

Gambar 1.1. Diagram Hasil Observasi Peningkatan Keaktifan Belajar Siswa Prasiklus, Siklus I, dan Siklus II

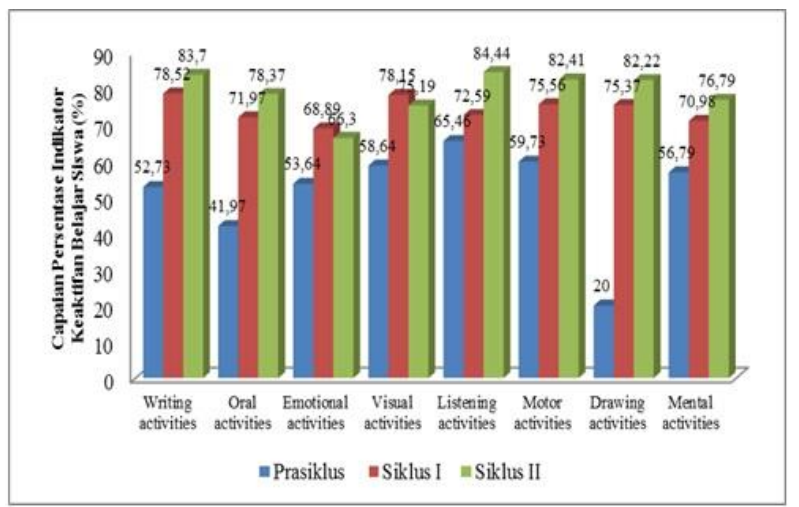

Gambar 1.2. Diagram Hasil Angket Peningkatan Keaktifan Belajar Siswa Prasiklus, Siklus I, dan Siklus II

Sedangkan hasil persentase motivasi dari penerapan model pembelajaran discovery learning ditunjukkan pada Gambar 1.3. dan Gambar 1.4.

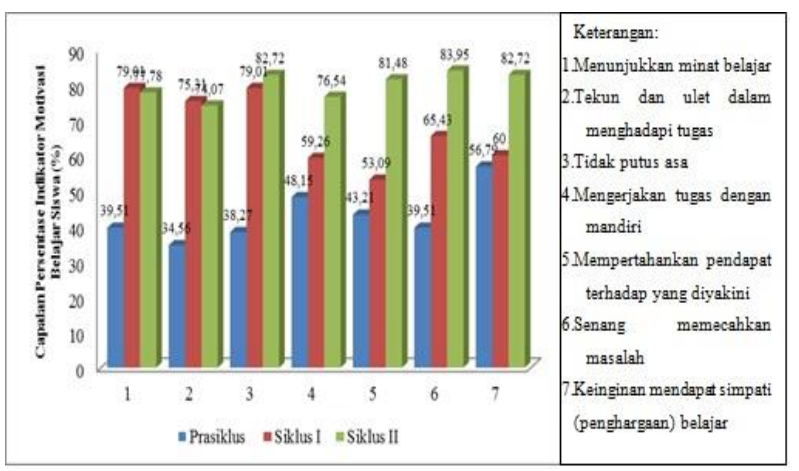

Gambar 1.3. Diagram Hasil Observasi Peningkatan Motivasi Belajar Siswa Prasiklus, Siklus I, dan Siklus II

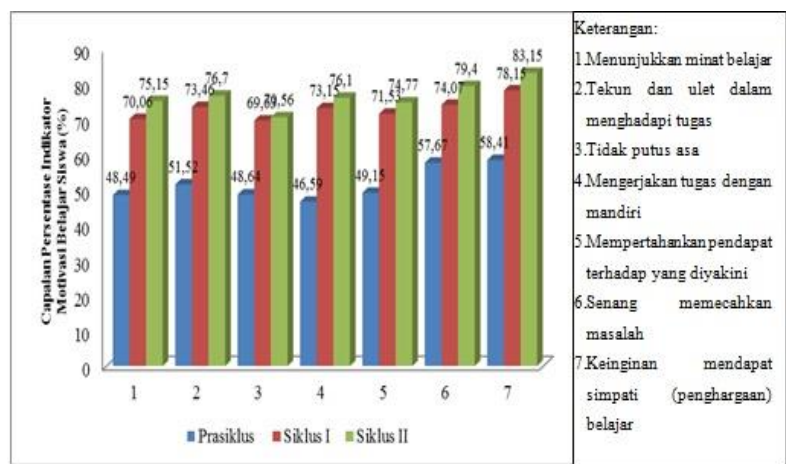

Gambar 1.4. Diagram Hasil Angket Peningkatan Motivasi Belajar Siswa Prasiklus, Siklus I, dan Siklus II

Penerapan model pembelajaran discovery learning di kelas XI IPA ICT 2 SMA Muhammadiyah 1 Karanganyar Tahun Pelajaran 2014/2015 memberi dampak positif dalam meningkatkan keaktifan dan motivasi belajar siswa selama proses pembelajaran. 
Discovery learning melihat murid sebagai pemilik peran yang jauh lebih aktif dalam pembelajaran mereka dan pendukung pendekatan ini berpendapat bahwa peningkatan belajar peserta didik disebabkan partisipasi aktif mereka dalam proses belajar (Patrick, 2012).

Hasil analisis data observasi berupa rata-rata capaian persentase keaktifan dan motivasi tiap siklus tindakan disajikan pada Gambar 1.4 dan Gambar 1.5.

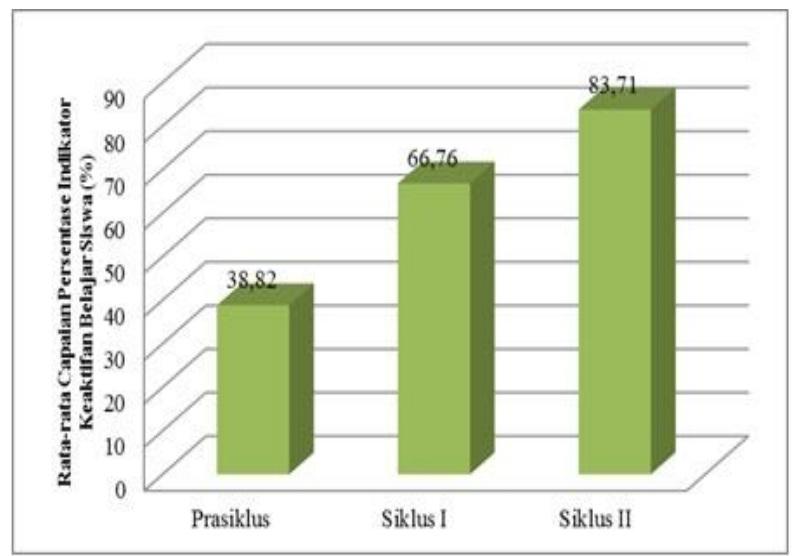

Gambar 1.4. Diagram Perbandingan Rata-rata Capaian Hasil Observasi Keaktifan Siswa pada Pra-Siklus, Siklus I, dan Siklus II

Hasil analisa penelitian dari observasi dan angket siklus II menunjukkan terjadi rata-rata peningkatan keaktifan dan motivasi belajar siswa dibandingkan dengan prasiklus dan siklus I. Rata-rata persentase observasi keaktifan belajar siswa meningkat sebesar $27,94 \%$ dari prasiklus sebesar 38,82\% menjadi $66,76 \%$ pada akhir siklus I. Sedangkan rata-rata persentase observasi keaktifan belajar siswa meningkat sebesar $16,95 \%$ dari siklus I sebesar $66,76 \%$ menjadi $83,71 \%$ pada akhir siklus II.

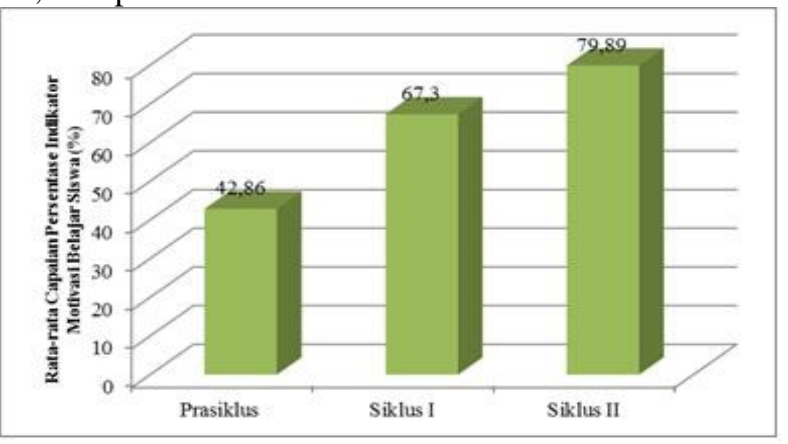

Gambar 1.5. Diagram Perbandingan Rata-rata Capaian Hasil Observasi Motivasi Siswa pada Pra-Siklus, Siklus I, dan Siklus II

Rata-rata persentase observasi motivasi belajar siswa meningkat sebesar $24,44 \%$ dari prasiklus sebesar 42,86\% menjadi 67,30\% pada akhir siklus I. Sedangkan rata-rata persentase observasi motivasi belajar siswa meningkat sebesar $12,59 \%$ dari siklus I sebesar $67,30 \%$ menjadi 79,89\% pada akhir siklus II.
Hasil analisis data angket berupa rata-rata capaian persentase keaktifan dan motivasi tiap siklus tindakan disajikan pada Gambar 1.6 dan Gambar 1.7.

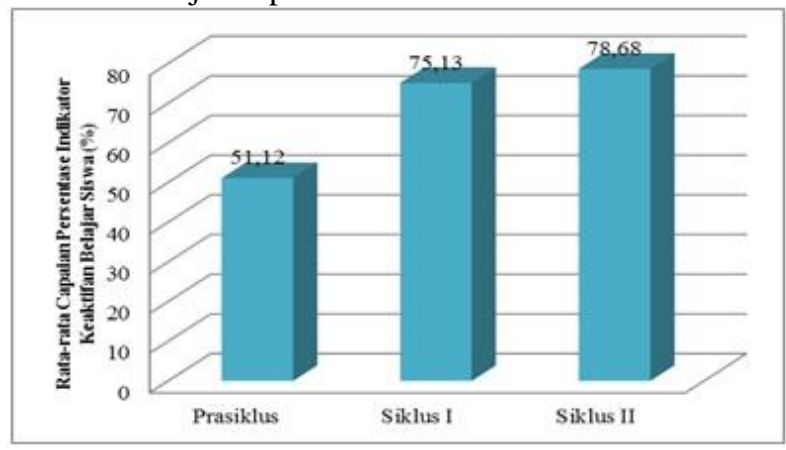

Gambar 1.6. Diagram Perbandingan Rata-rata Capaian Hasil Angket Keaktifan Siswa pada PraSiklus, Siklus I, dan Siklus II

Rata-rata persentase angket keaktifan siswa meningkat sebesar $24,01 \%$ dari prasiklus sebesar $51,12 \%$ menjadi $75,13 \%$ pada akhir siklus I. Sedangkan rata-rata persentase angket keaktifan siswa meningkat sebesar 3,55\% dari siklus I sebesar 75,13\% menjadi $78,68 \%$ pada akhir siklus II.

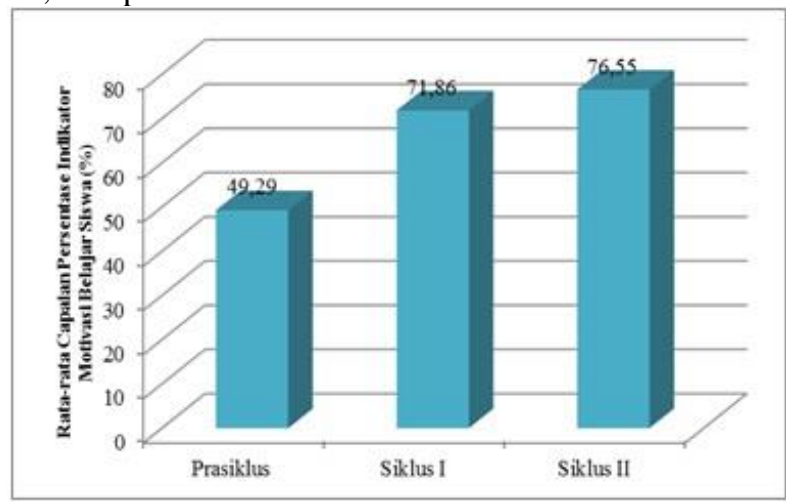

Gambar 1.7. Diagram Perbandingan Rata-rata Capaian Hasil Angket Motivasi Siswa pada PraSiklus, Siklus I, dan Siklus II

Rata-rata persentase angket motivasi belajar siswa meningkat sebesar $23,57 \%$ dari prasiklus sebesar 49,29\% menjadi $71,86 \%$ pada akhir siklus I. Sedangkan rata-rata persentase angket motivasi belajar siswa meningkat sebesar 4,69\% dari siklus I sebesar 71,86\% menjadi 76,55\% pada akhir siklus II.

Peningkatan yang sangat signifikan pada prasiklus dengan siklus I menunjukkan adanya perubahan positif yang mencolok sebagai akibat dari transformasi pembelajaran teacher centered menjadi student centered yaitu pembelajaran metode ceramah dan tanya jawab menjadi pembelajaran aktif discovery learning yang melibatkan siswa secara dominan dalam pembelajaran sehingga meningkatkan keaktifan dan motivasi siswa pada proses pembelajaran.

Model pembelajaran discovery learning meningkatkan peran aktif siswa yang terwujud dalam 
kegiatan eksplorasi, berpikir secara mandiri, penemuan yang melibatkan partisipasi dan interaksi yang tinggi untik menggunakan aspek kemampuan berpikir tingkat tinggi (Cruisckshank, Jenkins, \& Metcalf, 2009). Discovery learning melihat siswa sebagai pemilik peran yang jauh lebih aktif dalam pembelajaran mereka, sehingga meningkatkan kemampuan belajar dengan siswa dalam proses belajar. Pembelajaran ini menempatkan penekanan kuat pada kerja praktek yang diatur sedemikian rupa sehingga siswa melakukan observasi, mencari pola dan mempresentasikan penjelasan untuk pola-pola tersebut (Patrick, 2012). Ada tiga komponen utama discovery learning yaitu: 1) mengeksplorasi dan memecahkan untuk membuat, mengintegrasikan masalah, dan menggeneralisasi pengetahuan, 2) berbasis kegiatan yang mana siswa menentukan urutan dan frekuensi, 3) kegiatan untuk mendorong integrasi pengetahuan baru ke dalam basis pengetahuan yang dimiliki siswa (Bicknell \& Hoffman, 2000). Discovery learning dapat mencapai beberapa tingkatan dalam kegiatan belajar yang ditampakkan melalui keaktifan dan motivasi siswa dalam pembelajaran (Bicknell \& Hoffman, 2000).

Berdasarkan hasil wawancara tidak terstruktur dengan beberapa perwakilan siswa diperoleh respon yang bervariasi terhadap penerapan model pembelajaran discovery learning. Sejumlah narasumber mengaku kurang mampu beradaptasi dengan kegiatankegiatan model pembelajaran discovery learning dan lebih memilih mendengarkan dan mencatat penjelasan guru dibanding bersusah payah mencari jawaban dan penjelasan sendiri. Akan tetapi sebagian besar narasumber mengaku lebih senang dengan pembelajaran discovery learning dibandingkan ceramah langsung karena bisa melakukan investigasi, menghasilkan karya, dan berinteraksi dengan lebih banyak teman dalam belajar. Discovery learning juga membantu siswa untuk lebih memahami materi karena dalam pembelajaran ini siswa belajar untuk membangun suatu konsep materi dengan kemampuannya sendiri.

\section{SIMPULAN}

Pelaksanaan tindakan menggunakan model pembelajaran discovery learning di kelas XI IPA ICT 2 SMA Muhammadiyah 1 Karanganyar mampu meningkatkan keaktifan dan motivasi belajar biologi siswa yang diukur berdasarkan kualitas keaktifan dan motivasi.

\section{DAFTAR PUSTAKA}

Bennett, J. (2003). Teaching and Learning Science. London: Continuum.

Bicknell, H. T. \& Hoffman, P. S. (2000). Elicit, Engage, Experience, Explore: Discovery Learning in
Library Instruction. Reference Services Review. 28(4), 313 - 322.

Bruner, J.S. (1961). The Act of Discovery. Harvard Educational Review, 31(1): 21-23.

Cruisckshank, D. R., Jenkins D. B., \& Metcalf, K. K. (2009). The Act of Teaching. Boston : McGraw-Hill Higher Education

Djaali, H. (2011). Psikologi Pendidikan. Jakarta: Bumi Aksara.

Moelong, J. L. (2007). Metodologi Penelitian Kualitatif. Bandung: Remaja Rosdakarya.

Keraro, F. N., Wachanga, S. W., \& Orora, W. 2007. Effects of Cooperative Concept Mapping Teaching Approach on Secondary School Students Motivation in Biology, Gucha District, Kenya. International Journal of Science and Mathematics Education. Vol. 5: 111-124.

Kusumah, W., \& Dwitagama, D. (2012). Mengenal Penelitian Tidakan Kelas. Jakarta: PT Indeks.

Patrick, A. O. (2012). Which way do we go in the teaching of biology? Concept Mapping, Cooperative Learning or Learning Cycle?. International Journal of Science and Technology Education Research. 4(2), pp.1829.

Sardiman, A.M. (2012). Interaksi dan Motivasi Belajar Mengajar. Jakarta: Rajawali Press.

Shihusa, H., and Keraro, F.N. (2009). Using Advance Organizers to Enhance Students' Motivation in Learning Biology. Eurasia Journal of Mathematics, Science \& Technology Education. Vol. 5 (4): 413-420.

Slavin, R. (2009). Educational Psychology. U.S: McGraw Hill Company, Inc.

Veermans, K. (2003). Intelligent Support For Discovery Learning. Netherlands: Twente University Press. 